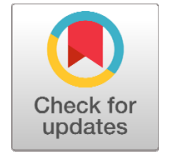

Received: Apr 28, 2021

Revised: May 20, 2021

Accepted: May 20, 2021

*Corresponding author

Ki-Chang Nam

Department of Animal Science and

Technology, Sunchon National

University, Suncheon 57922, Korea

Tel: +82-61-750-3231

E-mail: kichang@scnu.kr

Copyright () 2021 Korean Society of Animal Science and Technology.

This is an Open Access article distributed under the terms of the Creative Commons Attribution Non-Commercial License (http://creati vecommons.org/licenses/by-nc/4.0) which permits unrestricted non-commercial use, distribution, and reproduction in any medium, provided the original work is properly cited.

ORCID

Mahabbat Ali

https://orcid.org/0000-0002-5332-7758

Young-Sun Choi

https://orcid.org/0000-0002-6843-7423

Ki-Chang Nam

https://orcid.org/0000-0002-2432-3045

Competing interests

No potential conflict of interest

relevant to this article was reported.

Funding sources

This research was supported by the study on the improvement of animal performance to establish the breeding base of the black goat.

\section{Physicochemical attributes, free amino acids, and fatty acids of the five major cuts from Korean native black goat}

\author{
Mahabbat $\mathrm{Ali}^{1,2}$, Young-Sun $\mathrm{Choi}^{3}$ and Ki-Chang Nam ${ }^{1 *}$ \\ ${ }^{1}$ Department of Animal Science and Technology, Sunchon National University, Suncheon \\ 57922, Korea \\ ${ }^{2}$ Department of Animal Production and Management, Sher-e-Bangla Agricultural University, \\ Dhaka 1207, Bangladesh \\ ${ }^{3}$ Jeollanamdo Agricultural Research and Extension Services, Gangin 59213, Korea
}

\begin{abstract}
This study aimed to investigate the physicochemical traits, free amino acids, and fatty acid compositions of five different muscle cuts (loin, hind leg, neck, and foreleg) from Korean native black goat (KNBG). In a total, 21 castrated male KNGBs of 16 mon of age were reared with similar diets, conditions, and slaughtered. Results reveal that moisture content was lowest in rib compared to all tested groups $(p<0.05)$. Moreover, rib implied the highest lipid content compared to all cuts $(p<0.05)$. Protein and ash contents were lowest in the rib than all treatments except for the foreleg $(p<0.05)$. Shear force (kg.f) values related to meat tenderness did not show any significant differences among the five different cuts. Regards to free amino acid contents, glutamic acid was the highest in the neck $(p<0.05)$. The taurine and asparagine contents were highest in the foreleg $(p<0.05)$. The essential fatty acids; linoleic acid (18:2), and arachidonic (20:4) acid were highest in the meat excised from the hind leg $(p<0.05)$. Eicosatrienoic acid (20:3), and nervonic acid (24:1) were deemed important to brain functions highest in the hind leg $(p<0.05)$. Also, a similar trend was noted for polyunsaturated fatty acids (PUFA) contents in the hind leg $(p<0.05)$. Saturated fatty acids (SFA) were highest in rib compared to all treatments $(p<0.05)$. Taken together, our results indicate that proximate compositions, lipid contents, free amino acids, fatty acid compositions vary considerably with the anatomical locomotion of the muscles from KNBGs which could be a stratagem for consumer's preference of the meat and given nutritional and functional profile elsewhere.
\end{abstract}

Keywords: Korean native black goat, Goat meat cuts, Physicochemical traits, Free amino acid, Fatty acid compositions

\section{INTRODUCTION}

Korean native black goat (Capra bircus coreanae) is a typical native goat breed comprising more than $80 \%$ of the whole goat population in South Korea. Although KNBG meat has been consumed as medicine more than food [1], consumption of KNBG muscles has increased tremendously during the last few decades. Particularly, KNBG meat is consumed as a health-promoting food, especially for pregnant women, and for medicinal purposes for curing 
Acknowledgements

This research was supported by the study on the improvement of animal performance to establish the breeding base of the black goat.

Availability of data and material Upon reasonable request, the datasets of this study can be available from the corresponding author.

\section{Authors' contributions}

Conceptualization: Nam KC.

Data curation: Ali M.

Formal analysis: Ali M.

Methodology: Ali M, Choi YS.

Software: Choi YS.

Validation: Choi YS.

Investigation: Ali M, Nam KC

Writing - original draft: Ali M.

Writing - review \& editing: Ali M, Choi

YS, Nam KC.

Ethics approval and consent to participate

This article does not require IRB/ IACUC approval because there are no human and animal participants. ulcer healing or stomach inflammation [2]. Goats compared to sheep deposit more internal fat and less subcutaneous and intramuscular fat reported by many researchers [3-7]. Hence, consumers are attentive to goat meat as a country with a high prevalence of cardiovascular diseases. Relatively lean meat, especially influenced by many elements such as breed, age, sex, the plane of nutrition, and muscle compositions has been the subject of numerous reviews [8-13]. Although, there have been some studies with the lipid composition of goat meat in single muscles, different cuts of meat, and the entire carcass technological factors such as $\mathrm{pH}$ value, color, tenderness, protein content, fat content, and connective tissue content affect the meat quality. With the desire for leaner meat by consumers, meat from goats is attractive linked with other types of red meat [14]. However, goat meat is a darker red than lamb [15].

The fatty acid compositions of KNBG meat are not well known, although the physical characteristics and proximate composition of goat meat are influenced by muscle types [16]. Unlike the muscle type, postmortem (p.m.) changes in muscle tissues, pre-slaughter effects, stress, product handling, processing, and storage, microbiological numbers, and populations, etc. also influence the meat quality [17].

Moreover, the influence of anatomical location of muscles on the quality of goat meat was investigated by several authors $[18,19]$. Having in mind that the anatomical location of muscle can affect the meat quality [16].

The muscle fibers from meat are characterized by their morphological characters, and contractile and metabolic possessions [20]. Also, the contractile and metabolic possessions of muscle are distinguished by muscle fiber types. Generally, there are five diverse muscle fiber types in adult skeletal muscle, named slow-oxidative or type I, fast oxido-glycolytic or type IIA, and fast glycolytic IIX and IIB [21]. These muscle fibers are found in the muscle of meat from animals regulated by the predominant metabolic properties in their composition, and structure [22].

However, no data is available addressing the physicochemical characteristics, free amino acids, and fatty acid compositions of the major five meat cuts from KNBGs. Therefore, this study examined to investigate the physicochemical traits, free amino acids, and fatty acid compositions of five major cuts from KNBGs.

\section{MATERIALS AND METHODS}

\section{Animals and sample preparation for laboratory analysis}

A twenty-one castrated male of KNBGs were raised under the same diet and farming conditions at Gangin Jeollanamdo farm and slaughtered at 16 mon of age. After slaughtering and dressing, five separate cuts (loin, hind leg, neck, and foreleg) were collected and analyzed. The meat quality characteristics, free amino acid concentrations, and fatty acid compositions were investigated.

\section{Proximate composition}

Moisture contents of five different meat cuts excised from KNBGs were determined by drying the samples $(3 \mathrm{~g})$ at $102^{\circ} \mathrm{C}$ [23]. The contents of crude protein were measured by the method 
suggested by [23]. With a ratio to chloroform/methanol (2:1), using $5 \mathrm{~g}$ of meat, lipids were determined under the procedure described by [24].

\section{Water holding capacity, pH, and cooking loss}

With a slightly modified method, adopted elsewhere [25], $5 \mathrm{~g}$ of the ground meat sample from each cut was centrifuged at $4^{\circ} \mathrm{C}$ for $10 \mathrm{~min}$ at $1,200 \times \mathrm{g}$ with a centrifuge machine (Combi 514-R, HANIL, Gimpo, Korea), and the water holding capacity was measured. The pH values from five different muscle cuts were measured by taking $2 \mathrm{~g}$ of the blending meat samples mixed with $18 \mathrm{~mL}$ of distilled water followed by homogenization at $1,200 \times \mathrm{g}$ for $30 \mathrm{~s}$ using a homogenizer (Polytron PT 10-35 GT, Kinematica, Malters, Switzerland). By using a pH meter (Seven Excellence $^{\mathrm{TM}}$, METTLER TOLEDO, Greifensee, Switzerland) at room temperature $\mathrm{pH}$ was recorded. For cooking loss, an electric grill (Nova EMG-533, 1,400 W, Evergreen enterprise, Yongin, Korea) was used to heat the meat cuts for $60 \mathrm{~s}$ until to reach the internal temperature of the meat sample at $72^{\circ} \mathrm{C}$ with the standardized cuts sample $(30 \times 50 \times 10 \mathrm{~mm})$. Meat color was performed by a colorimeter (CR-410, Minolta, Tyoko, Japan). The shear force values of the five different goat meat (cooked meat sample) were designed in a cubic form $(30 \times 50 \times$ $10 \mathrm{~mm}$ ) by using a Warner-Bratzler shear attachment equipped on a texture analyzer (TA-XT2, Stable Micro System, Surrey, UK.). The maximum shear force value $(\mathrm{kg} \cdot \mathrm{f})$ was recorded for each sample. The test and pre-test of the speeds were set to $2.0 \mathrm{~mm} / \mathrm{s}$, and post-test speeds set to $5.0 \mathrm{~mm} / \mathrm{s}$.

\section{Free amino acids}

The soluble amino acid compositions of five goat meat cuts were quantified by using a slightly modified method described by [26]. HPLC analyses of free amino acids were attained with an S433 auto analyzer, separation of cation column (LCAK07/li; $4.6 \times 150 \mathrm{~mm}$ ), at buffer revolution (A: $\mathrm{pH}$ 2.90; $\mathrm{B}: \mathrm{pH} 4.20$; $\mathrm{C}: \mathrm{pH} 8.00$ ), lithium citrate buffer solution with a buffer flow rate $0.45 \mathrm{~mL} / \mathrm{min}$, ninhydrin flow rate $0.25 \mathrm{~mL} / \mathrm{min}$, and column temperature $37^{\circ} \mathrm{C}$.

\section{Fatty acid compositions}

The fatty acid compositions of five meat cut from KNBGs were estimated by the method of [27], with a minor modification. The test was performed via a Gas Chromatograph-Flame Ionization Detector (7890 series, Agilent, Santa Clara, CA, USA) under the following conditions: injector split mode with a split ratio of $25: 1$, temperature $250^{\circ} \mathrm{C}$. High pureness air, high purity of $\mathrm{H}_{2}$, and high purity of $\mathrm{He}$ were used as hauler gases. The flow rate was maintained at $40 \mathrm{~mL} / \mathrm{min}$ for $\mathrm{H}_{2}$ and $400 \mathrm{~mL} / \mathrm{min}$ for air. An HP-88 column $(60 \mathrm{~m} \times 250$ $\mu \mathrm{m} \times 0.2 \mathrm{~mm})$ was used for the investigation. The fatty acid compositions were stated as a percentage.

\section{Statistical analysis}

Data obtained were studied by multiple assay techniques, applying the Student-Newman-Keuls for significance test $(p<0.05)$ adopting the general linear model of the SAS program [28]. 
Significant differences were marked by applying the one-way ANOVA. Each treatment was executed in five replication, and results are presented as the SEM.

\section{RESULTS AND DISCUSSION}

\section{Proximate composition}

The proximate compositions of the five different goat meat cuts from KNBGs are presented in Table 1 . In this study, muscles or cuts significantly varied owing to proximate compositions. The result shows that moisture content in all five muscles or cuts varied ranges from $65.98 \%$ (rib) to $75.99 \%$ (neck). The result shows that meat from rib implied the lowest moisture and ash contents compared with all tested groups $(p<0.05)$. Subsequently, much higher lipid content was found in the rib compared to the all tested groups $(p<0.05)$ and was due to individual muscle fat deposition capacity [20]. However, lipid content dominant in rib occupied with intermediate muscles structure (previously reported) might be explained by the propensity to accumulate fat cells in the extravascular area [29]. Notably, a significant variation was observed among the tested groups for crude protein contents $(p<0.05)$. In between loin and rump [30] found a similar proximate composition with black goat meat. The variation of the proximate composition within the breed in different muscles or cuts due to attributes as muscle composition and their specific metabolic activities [20]. It has been reported by [31] that meat from black goat implied $74.40 \%$ to $76.04 \%$ moisture, $19.83 \%$ to $20.47 \%$ crude protein, $1.64 \%$ to $3.56 \%$ crude fat, and $1.04 \%$ to $1.11 \%$ crude ash as a part of the proximate compositions. Hwang et al [32] have reported that the black goat meat contained fat between $1.12 \%$ and $1.59 \%$. On the other hand, [33] have coincided that the crude fat content of the black goat meat was $7.81 \%$ to $9.43 \%$ at different ages of castration. Apart from these studies, a study was conducted owing to the proximate composition of the black goat meat was $67.0 \%$ to $75.2 \%$ moisture, $18.9 \%$ to $24.8 \%$ crude protein, $3.25 \%$ to $12.6 \%$ crude fat, and $0.95 \%$ to $1.19 \%$ crude ash, depending on the breed [34]. Castration increases fat contents compared to the noncastrated animal because castration changes hormonal mediation of nitrogen metabolism controlling the accumulation of muscle tissue [35] and is related to the control and concentrations of growth hormones and metabolites. It is well defined that, numerous biochemical and fundamental physiognomies of muscle fibers have an independent role in the muscle resulting in meat quality variation with different

Table 1. Proximate composition (\%) of five different meat cuts from KNBG

\begin{tabular}{|c|c|c|c|c|c|c|}
\hline \multirow{2}{*}{ Items } & \multicolumn{5}{|c|}{ Cuts } & \multirow{2}{*}{ SEM $^{1)}$} \\
\hline & Loin & Hind leg & Neck & Rib & Foreleg & \\
\hline Moisture & $74.53^{\mathrm{a}}$ & $75.65^{a}$ & $75.99^{a}$ & $65.98^{b}$ & $74.73^{\mathrm{a}}$ & 0.64 \\
\hline Fat & $2.38^{b}$ & $1.82^{b}$ & $2.92^{b}$ & $14.06^{\mathrm{a}}$ & $4.56^{b}$ & 0.85 \\
\hline Crude protein & $23.40^{\mathrm{a}}$ & $22.80^{\mathrm{a}}$ & $21.22^{b}$ & $19.74^{c}$ & $20.37^{b c}$ & 0.39 \\
\hline Crude ash & $0.92^{\mathrm{a}}$ & $0.96^{a}$ & $0.87^{\mathrm{a}}$ & $0.73^{b}$ & $0.93^{\mathrm{a}}$ & 0.03 \\
\hline
\end{tabular}


anatomical location [35]. These factors, which are often difficult to control between studies, include differences in maturity, breed, production systems, and feeding management of animals used in these studies.

Quality characteristics (meat color, pH, water holding capacity, cooking loss, and shear force)

Table 2 lists the meat quality characteristics of five different meat cuts from KNBGs. Among the quality characteristics of meat color is one of the most appraisal traits of fresh meat [9]. Results imply that a significant variation was noted among the five meat cuts for lightness $(p$ $<0.05$ ) whereas no significant break was noted for redness and yellowness among the tested groups $(p>0.05)$. The most important quality parameter $\mathrm{pH}$ ranged from 6.21 to 6.63 among the five meat cuts and varied significantly in the line of tested groups. Almost all individual $\mathrm{pH}$ values in all five muscles or cuts, were within the characteristics range for red (goat) meat [36]. In a previous study, it has been reported that muscle $\mathrm{pH}$ varied following the muscle types of the examined sample. Many researchers reported that meat with type I muscles showed a higher $\mathrm{pH}$, lower buffering capacity with lower lactate production whereas meat with type II B muscles resembles the lower $\mathrm{pH}$, higher lactate, and higher buffering activity [37]. Owing to cooking loss, varied ranges from $11.20 \%$ to $14.93 \%$ in all tested cuts. It is also related to protein denaturation and cooking processes, such as temperature and time at the heating phase [38]. Shear force values that resemble the meat tenderization did not show any significant variation in the meat cuts from KNBGs $(p>0.05)$. Nevertheless, numerically, shear force values varied to the anatomical location of the muscles or cuts. Unlike values we found in our study, shear force values for muscles from castrated males were not significantly different while the author reported with leg and loin from goat meat [39]. Our data from this study indicate that castration effects to meat tenderness may depend on the measurement of postmortem and have implicated increased collagen solubility in the myofibrillar tenderness system [40]. It has been reported that castrated animals have a lower shear force value than non-castrated animals implying that castration would lead to increased mRNA levels of calpains and ultimately reduce calpastatin. However, apart from castration meat tenderness also depend on various intrinsic factors such as

Table 2. The physicochemical traits of five different meat cuts from KNBG

\begin{tabular}{|c|c|c|c|c|c|c|}
\hline \multirow{2}{*}{ Items } & \multicolumn{5}{|c|}{ Cuts } & \multirow{2}{*}{ SEM $^{1)}$} \\
\hline & Loin & Hind leg & Neck & Rib & Foreleg & \\
\hline CIE L* & $32.48^{\mathrm{abc}}$ & $31.06^{b c}$ & $30.47^{c}$ & $34.64^{\mathrm{a}}$ & $34.04^{a b}$ & 0.90 \\
\hline CIE $a^{*}$ & 18.84 & 18.08 & 19.39 & 20.35 & 19.49 & 1.00 \\
\hline CIE $b^{*}$ & 5.20 & 4.77 & 7.13 & 6.72 & 6.51 & 0.88 \\
\hline $\mathrm{pH}$ & $6.21^{b}$ & $6.37^{\mathrm{ab}}$ & $6.63^{\mathrm{a}}$ & $6.23^{b}$ & $6.56^{a}$ & 0.08 \\
\hline Cooking loss (\%) & $11.22^{b}$ & $11.20^{b}$ & $14.37^{\mathrm{a}}$ & $14.93^{\mathrm{a}}$ & $12.86^{a b}$ & 0.74 \\
\hline Shear force (kg.f) & 4.81 & 6.04 & 5.60 & 5.93 & 4.31 & 0.90 \\
\hline
\end{tabular}


production systems and the age of slaughter [41]. In general shear force values depends on muscle's fiber density, muscle fiber size, myofibril index, sarcomere length, collagen content, and intrinsic enzymes of the meat. Meat tenderness is affected by the origin of the animal as well as their age, breed, gender, and environmental conditions, and period of meat aging [42].

\section{Free amino acids}

Table 3 lists the free amino acid compositions excised from five different meat cuts of KNBGs. The most important functional amino acid, taurine contents were higher in the foreleg cut compared with all treatments $(p<0.05)$ that might be attributed to the oxidative muscle's activity and capacity [43]. A similar trend found for asparagine resembles as biosynthesis of proteins in meat in the foreleg. One of the savory or umami amino acids, glutamic acid contents

Table 3. Free amino acid $(\mathrm{mg} / 100 \mathrm{~g})$ of five different meat cuts from KNBG

\begin{tabular}{|c|c|c|c|c|c|c|}
\hline \multirow{2}{*}{$\mathrm{FAA}^{1)}$} & \multicolumn{5}{|c|}{ Cuts } & \multirow{2}{*}{ SEM $^{2)}$} \\
\hline & Loin & Hind leg & Neck & Rib & Foreleg & \\
\hline Taurine & $51.03^{d c}$ & $81.96^{b}$ & $84.72^{b}$ & $83.44^{b}$ & $119.65^{a}$ & 6.58 \\
\hline Aspartic acid & 5.67 & 5.59 & 7.16 & 6.33 & 5.90 & 0.88 \\
\hline Threonine & 4.26 & 3.35 & 3.48 & 4.75 & 4.29 & 0.70 \\
\hline Serine & 6.64 & 5.04 & 4.51 & 4.88 & 5.87 & 0.89 \\
\hline Asparagine & $3.38^{b}$ & $4.67^{b}$ & $2.40^{b}$ & $3.27^{b}$ & $12.80^{\mathrm{a}}$ & 1.40 \\
\hline Glutamic acid & $31.23^{b}$ & $28.26^{b}$ & $54.27^{\mathrm{a}}$ & $37.96^{b}$ & $14.01^{\mathrm{C}}$ & 4.60 \\
\hline Glycine & 22.28 & 19.73 & 20.77 & 28.84 & 30.75 & 3.20 \\
\hline Alanine & 21.34 & 24.88 & 27.81 & 33.19 & 33.36 & 2.76 \\
\hline Valine & $4.71^{\mathrm{a}}$ & $3.30^{\mathrm{ab}}$ & $2.78^{a b}$ & $2.56^{b}$ & $3.34^{\mathrm{ab}}$ & 0.49 \\
\hline Methionine & 3.04 & 2.09 & 1.79 & 1.76 & 1.82 & 0.32 \\
\hline Isoleucine & $3.01^{\mathrm{ab}}$ & $2.52^{b}$ & $4.32^{\mathrm{a}}$ & $4.51^{\mathrm{a}}$ & $4.62^{\mathrm{a}}$ & 0.42 \\
\hline Leucine & $7.22^{\mathrm{a}}$ & $4.59^{b}$ & $2.05^{b}$ & $2.42^{b}$ & $2.17^{b}$ & 0.73 \\
\hline Tyrosine & $4.21^{\mathrm{a}}$ & $2.13^{\mathrm{ab}}$ & $0.91^{b}$ & $2.31^{\mathrm{ab}}$ & $2.53^{\mathrm{ab}}$ & 0.53 \\
\hline Histidine & 3.13 & 1.71 & 3.06 & 2.64 & 2.51 & 0.60 \\
\hline Tryptophan & $3.73^{\mathrm{a}}$ & $2.45^{b}$ & $1.90^{b}$ & $2.52^{b}$ & $1.88^{b}$ & 0.31 \\
\hline Carnosine & $3.11^{\mathrm{a}}$ & $2.21^{b}$ & $1.66^{b}$ & $2.05^{b}$ & $1.77^{\mathrm{b}}$ & 0.28 \\
\hline Lysine & 4.71 & 3.22 & 3.62 & 3.47 & 6.67 & 0.82 \\
\hline Arginine & 2.22 & 2.34 & 2.79 & 2.16 & 4.32 & 0.77 \\
\hline Total free amino acids & $184.96^{b}$ & $200.07^{b}$ & $231.75^{\mathrm{ab}}$ & $230.77^{\mathrm{ab}}$ & $259.82^{\mathrm{a}}$ & 13.02 \\
\hline (Sweet + Umami) A.A. & 93.82 & 89.15 & 116.86 & 116.36 & 107.74 & 7.62 \\
\hline Bitter A.A. & 23.31 & 16.53 & 16.78 & 16.05 & 18.76 & 2.08 \\
\hline (Sweet + Umami) A.A. / Bitter A.A. & $4.15^{b}$ & $5.43^{\mathrm{ab}}$ & $7.17^{\mathrm{a}}$ & $7.45^{\mathrm{a}}$ & $5.85^{\mathrm{ab}}$ & 0.66 \\
\hline
\end{tabular}

${ }^{1)}($ Sweet + Umami) A.A.: asparagine + threonine + serine + glutamic acid + glycine + alanine + lysine

Bitter A.A.: valine + methionine + isoleucine + leucine + histidine + arginine.

2) $n=5$.

${ }^{a-d}$ Mean values with different letters within the same row differ significantly $(p<0.05)$

KNBG, Korean native black goat; FAA, free amino acid. 
were significantly higher in the neck in the all tested groups $(p<0.05)$ mostly found in oxidative or intermediate types of muscle [43]. ATP generating amino acid, leucine contents were significantly higher in loin than other cuts. Moreover, antioxidative amino acid, carnosine contents were significantly higher in loin muscle or cut compared with all other tested groups. It has been reported that carnosine content is highly correlated with glycolytic muscle fiber [43]. The varied amino acids among the five muscles or cuts can be attributed to muscle compositions and functional effect, which depends on the aminopeptidase and hydrolytic activity toward the increased group with the proteolysis of muscle by an enzyme known as calpain $[44,45]$. Thus different muscles of meat cuts from KNBGs show their unique amino acid characteristics could be helpful from a nutritional point of view as well as meat flavor chemistry.

\section{Fatty acid compositions}

Table 4 lists the fatty acid compositions of the different meat cuts from KNBGs. The fatty acid compositions of muscles are an important factor in determining the nutritional quality of meat or adipose tissue subjected with special attention in human health. Result reveals that the essential fatty acids; linoleic acid (18:2), and arachidonic acid (20:4) contents were significantly higher in the hind leg compared with the other tested groups $(p<0.05)$. The hind leg also

Table 4. Fatty acid compositions (\%) of five different meat cuts from KNBG

\begin{tabular}{|c|c|c|c|c|c|c|}
\hline \multirow{2}{*}{ Fatty acid } & \multicolumn{5}{|c|}{ Cuts } & \multirow{2}{*}{ SEM $^{1)}$} \\
\hline & Loin & Hind leg & Neck & Rib & Foreleg & \\
\hline $14: 0$ & $3.81^{\mathrm{ab}}$ & $3.30^{b}$ & $4.26^{\mathrm{ab}}$ & $5.02^{\mathrm{a}}$ & $4.08^{a b}$ & 0.33 \\
\hline $16: 0$ & $23.44^{a}$ & $20.78^{b}$ & $23.03^{a}$ & $23.73^{a}$ & $22.14^{\mathrm{ab}}$ & 0.60 \\
\hline $16: 1$ & $2.82^{b c}$ & $2.39^{c}$ & $3.39^{\mathrm{a}}$ & $2.65^{b c}$ & $3.06^{\mathrm{ab}}$ & 0.15 \\
\hline 18:0 & $9.94^{b}$ & $10.84^{b}$ & $10.26^{b}$ & $12.54^{\mathrm{a}}$ & $10.26^{b}$ & 0.52 \\
\hline 18:1 & $44.42^{\mathrm{a}}$ & $38.49^{b}$ & $39.70^{\mathrm{ab}}$ & $37.48^{b}$ & $40.51^{\mathrm{ab}}$ & 1.37 \\
\hline $18: 2$ & $3.60^{b}$ & $6.12^{\mathrm{a}}$ & $4.05^{b}$ & $3.83^{b}$ & $4.58^{b}$ & 0.44 \\
\hline $18: 3$ & 0.26 & 0.27 & 0.29 & 0.28 & 0.26 & 0.02 \\
\hline $20: 2$ & 0.27 & 0.70 & 0.35 & 0.40 & 0.47 & 0.11 \\
\hline $20: 3$ & $0.14^{b}$ & $0.28^{a}$ & $0.14^{b}$ & $0.14^{b}$ & $0.18^{b}$ & 0.03 \\
\hline $20: 4$ & $1.73^{b}$ & $3.72^{\mathrm{a}}$ & $1.56^{b}$ & $1.62^{b}$ & $2.21^{b}$ & 0.36 \\
\hline $24: 1$ & $0.21^{b}$ & $0.41^{\mathrm{a}}$ & $0.24^{b}$ & $0.20^{b}$ & $0.28^{b}$ & 0.03 \\
\hline SFA & $37.65^{b}$ & $35.35^{b}$ & $38.08^{b}$ & $41.95^{\mathrm{a}}$ & $36.99^{b}$ & 1.09 \\
\hline UFA & $55.80^{a}$ & $54.49^{a}$ & $52.22^{\mathrm{ab}}$ & $49.16^{b}$ & $53.64^{a}$ & 1.20 \\
\hline MUFA & $49.80^{a}$ & $43.39^{b}$ & $45.85^{\mathrm{ab}}$ & $42.89^{b}$ & $45.95^{\mathrm{ab}}$ & 1.34 \\
\hline PUFA & $6.00^{b}$ & $11.10^{\mathrm{a}}$ & $6.37^{b}$ & $6.28^{b}$ & $7.70^{b}$ & 0.85 \\
\hline UFA/SFA & $1.50^{\mathrm{a}}$ & $1.55^{\mathrm{a}}$ & $1.37^{\mathrm{ab}}$ & $1.18^{b}$ & $1.46^{\mathrm{a}}$ & 0.07 \\
\hline$n-6 / n-3$ & 14.25 & 22.76 & 15.04 & 14.15 & 18.13 & 2.19 \\
\hline
\end{tabular}


riches with eicosatrienoic acid (20:3) and nervonic acid (24:1) related to the development of the human brain. And even, most desirable fatty acids, polyunsaturated fatty acids (PUFAs) were also higher in the hind leg compared with other treatments in the same line $(p<0.05)$. Moreover, total SFAs were highest in the meat from the rib and that was the propensity of lipid content mentioned in the proximate composition's segment. Differences in muscle fiber types, fatty acid compositions are reflected with phospholipid and intrinsic mechanism of the individual muscle and reported [46]. Due to having higher phospholipids in the red muscle (hind leg), it occupies a higher percentage of PUFA [46] resulting in a rich with linoleic acid, arachidonic acid, eicosatrienoic acid and, nervonic acid content. Likewise, our compiled data suggested that the different anatomical locations of the muscles contained different fatty acids agreed with [47]. The fatty acid contents varied within the breed in the five muscles might be attenuated to muscle types with their metabolic activities and deposition pattern in the muscle [48]. Regarding breed, age, live weight, rearing condition, and age insist the fatty acid compositions based on muscle composition and metabolic functions of perspective muscle [17] resulting in the depots of higher internal fat. Thus, it needs to research and attention regards to goat meat's fatty acid composition might be beneficial to the nutrition as well as breeding policy with improved goat meat production. However, the quantitative quality of fatty acids contents observed in this study among the different five meat cuts will be helpful to the health conscience consumers while preferring the cuts.

\section{CONCLUSIONS}

Data from the current study confirms that variation to proximate composition, meat quality attributes, free amino acid concentrations, and fatty acid compositions among five different cuts varied by muscle's locomotion, types, and instinct mechanism within the breed. Moreover, of them, certain cuts were nutritionally got preferred, which could be attenuated as a stratagem for health conscience consumers. However, despite having differences in the cuts regards to muscle types and compositions, five different cuts offer similar tenderness in the line that could be attenuated in further goat meat tenderization with emphasis on castration and ages. With the least amount of consumer satisfaction, further studies should be warranted with morphology traits such as total number of fiber (TNF) and cross-sectional area of the fibers (CSFA) of the chevon to describe the overall goat meat quality precisely.

\section{REFERENCES}

1. Son YS. Production and uses of Korean native black goat. Small Rumin Res. 1999;34:303-8. https://doi.org/10.1016/S0921-4488(99)00081-4

2. Min TG, Kong KO, Song HB. The marketing of the goat in Korea [Internet]. 1999 [cited $2021 \mathrm{Fed} \mathrm{30]}$. http://citeseerx.ist.psu.edu/viewdoc/download?doi=10.1.1.196.3323\&rep=rep1\& type=pdf

3. Smith GC, Carpenter ZL, Shelton M. Effect of age and quality level on the palatability of goat meat. J Anim Sci. 1978;46:1229-35. https://doi.org/10.2527/jas1978.4651229x 
4. Kirton AH. Characteristics of goat meat including carcass quality and methods of slaughter: goat meat production in Asia. In: Proceedings of a Workshop Held in Tando Jam, Pakistan; 1988.

5. Van Niekerk WA, Casey NH. The Boer goat. II. Growth, nutrient requirements, carcass and meat quality. Small Rumin Res. 1988;1:355-68. https://doi.org/10.1016/0921-4488(88)90061-2

6. Casey NH, Webb EC. Managing goat production for meat quality. Small Rumin Res. 2010;89:218-24. https://doi.org/10.1016/j.smallrumres.2009.12.047

7. Colomer-Rocher F, Kirton AH, Mercer GJK, Duganzich DM. Carcass composition of New Zealand Saanen goats slaughtered at different weights. Small Rumin Res. 1992;7:161-73. https://doi.org/10.1016/0921-4488(92)90205-I

8. Ali M, Park JY, Lee SY, Choi YS, Nam KC. Physicochemical and microbial characteristics of longissimus lumborum and biceps femoris muscles in Korean native black goat with wet-aging time. J Anim Sci Technol. 2021;63:149-59.

9. Webb EC, Casey NH, Simela L. Goat meat quality. Small Rumin Res. 2005;60:153-66. https://doi.org/10.1016/j.smallrumres.2005.06.009

10. McMillin KW, Brock AP. Production practices and processing for value-added goat meat. J Anim Sci. 2005;83:E57-E68. https://doi.org/10.2527/2005.8313_supplE57x

11. Dhanda JS, Taylor DG, Murray PJ. Part 1. growth, carcass and meat quality parameters of male goats: effects of genotype and liveweight at slaughter. Small Rumin Res. 2003; 50:57-66. https://doi.org/10.1016/S0921-4488(03)00112-3

12. Kadim IT, Mahgoub O. Nutritive value and quality characteristics of goat meat. Goat meat production and quality. 3rd ed. Cambridge, MA: CABI; 2012. p. 292-323.

13. Mahgoub O, Kadim IT, Lu CD. Overview of the global goat meat sector. Goat meat production and quality. 3rd ed. Cambridge, MA: CABI; 2012. p. 1-14.

14. Potchoiba MJ, Lu CD, Pinkerton F, Sahlu T. Effects of all-milk diet on weight gain, organ development, carcass characteristics and tissue composition, including fatty acids and cholesterol contents, of growing male goats. Small Rumin Res. 1990;3:583-92. https://doi.org/10.1016/ 0921-4488(90)90053-9

15. Babiker SA, El Khider IA, Shafie SA. Chemical composition and quality attributes of goat meat and lamb. Meat Sci. 1990;28:273-7. https://doi.org/10.1016/0309-1740(90)90041-4

16. Tomović VM, Jokanović MR, Švarc-Gajić JV, Vasiljević IM, Šojić BV, Škaljac SB, et al. Physical characteristics and proximate and mineral composition of Saanen goat male kids meat from Vojvodina (Northern Serbia) as influenced by muscle. Small Rumin Res. 2016; 145:44-52. https://doi.org/10.1016/j.smallrumres.2016.10.019

17. Banskalieva V, Sahlu T, Goetsch AL. Fatty acid composition of goat muscles and fat depots: a review. Small Rumin Res. 2000;37:255-68. https://doi.org/10.1016/S0921-4488(00)00128-0

18. Marinova P, Banskalieva V, Alexandrov S, Tzvetkova V, Stanchev H. Carcass composition and meat quality of kids fed sunflower oil supplemented diet. Small Rumin Res. 2001;42: 217-25. https://doi.org/10.1016/S0921-4488(01)00245-0

19. Stanisz M, Ludwiczak A, Pietrzak M, Ślósarz P. The quality of meat and edible by-products from kids with different inheritance of Boer goat. Small Rumin Res. 2015;125:81-7. https://doi.org/10.1016/j.smallrumres.2015.02.010

20. Lee SH, Joo ST, Ryu YC. Skeletal muscle fiber type and myofibrillar proteins in relation to meat quality. Meat Sci. 2010;86:166-70. https://doi.org/10.1016/j.meatsci.2010.04.040

21. Schiaffino S, Reggiani C. Molecular diversity of myofibrillar proteins: gene regulation and functional significance. Physiol Rev. 1996;76:371-423. https://doi.org/10.1152/physrev.1996. 
76.2 .371

22. Ozawa S, Mitsuhashi T, Mitsumoto M, Matsumoto S, Itoh N, Itagaki K, et al. The characteristics of muscle fiber types of longissimus thoracis muscle and their influences on the quantity and quality of meat from Japanese Black steers. Meat Sci. 2000;54:65-70. https://doi.org/10.1016/S0309-1740(99)00072-8

23. AOAC [Association of Official Analytical Chemists] International. Official methods of analysis of the AOAC International. Gaithersburg, MD: AOAC International; 2000.

24. Folch J, Lees M. Proteolipides, a new type of tissue lipoproteins: their isolation from brain. J Biol Chem. 1951;191:807-17. https://doi.org/10.1016/S0021-9258(18)55985-8

25. Uttaro BE, Ball RO, Dick P, Rae W, Vessie G, Jeremiah LE. Effect of ractopamine and sex on growth, carcass characteristics, processing yield, and meat quality characteristics of crossbred swine. Anim Sci J. 1993;71:2439-49. https://doi.org/10.2527/1993.7192439x

26. Hughes MC, Kerry JP, Arendt EK, Kenneally PM, McSweeney PLH, O'neill EE. Characterization of proteolysis during the ripening of semi-dry fermented sausages. Meat Sci. 2002;62:205-16. https://doi.org/10.1016/S0309-1740(01)00248-0

27. O'Fallon JV, Busboom JR, Nelson ML, Gaskins CT. A direct method for fatty acid methyl ester synthesis: application to wet meat tissues, oils, and feedstuffs. Anim Sci J. 2007;85: 1511-21. https://doi.org/10.2527/jas.2006-491

28. SAS. SAS program, version 9.4. Cary, NC: SAS Institute; 2003.

29. Alasnier C, Rémignon H, Gandemer G. Lipid characteristics associated with oxidative and glycolytic fibres in rabbit muscles. Meat Sci. 1996;43:213-24. https://doi.org/10.1016/S03091740(96)00015-0

30. Kim HJ, Kim HJ, Jang A. Nutritional and antioxidative properties of black goat meat cuts. Asian-Australas J Anim Sci. 2019;32:1423-9. https://doi.org/10.5713/ajas.18.0951

31. Choi SH, Cho YM, Kim MJ, Chai HS, Lee JW, Kim YG. Effect of castration and searing of the musk gland on growth performance and meat quality of Korean native goats. J Anim Sci. 2000;42:891-6.

32. Hwang YH, Joo SH, Bakhsh A, Ismail I, Joo ST. Muscle fiber characteristics and fatty acid compositions of the four major muscles in Korean native black goat. Korean J Food Sci Anim Resour. 2017;37:948-54. https://doi.org/10.5851/kosfa.2017.37.6.948

33. Kim BK, Hwang EG, Kim SM. Meat quality and sensory properties of Korean native black goat by different castration age. Korean J Food Sci Anim Resour. 2010;30:419-26. https://doi.org/10.5851/kosfa.2010.30.3.419

34. Sebsibe A. Sheep and goat meat characteristics and quality. In: Yami A, Merkel RC, editors. Sheep and goat production handbook for Ethiopia. Addis Ababa, Ethiopia: Ethiopian Sheep and Goats Productivity Improvement Program (ESGPIP); 2008. p. 325-340.

35. Galbraith H, Dempster DG, Miller TB. A note on the effect of castration on the growth performance and concentrations of some blood metabolites and hormones in British Friesian male cattle. Anim Sci J. 1978;26:339-42. https://doi.org/10.1017/S0003356100040964

36. Madruga MS, Elmore JS, Dodson AT, Mottram DS. Volatile flavour profile of goat meat extracted by three widely used techniques. Food Chem. 2009;115:1081-7. https://doi.org/10. 1016/j.foodchem.2008.12.065

37. Listrat A, Lebret B, Louveau I, Astruc T, Bonnet M, Lefaucheur L, et al. How muscle structure and composition influence meat and flesh quality. Sci World J. 2016:3182746. https://doi.org/10.1155/2016/3182746

38. Aaslyng MD, Bejerholm C, Ertbjerg P, Bertram HC, Andersen HJ. Cooking loss and 
juiciness of pork in relation to raw meat quality and cooking procedure. Food Qual Prefer. 2003;14:277-88. https://doi.org/10.1016/S0950-3293(02)00086-1

39. Seideman SC, Cross HR, Oltjen RR, Schanbacher BD. Utilization of the intact male for red meat production: a review. Anim Sci J. 1982;55:826-40. https://doi.org/10.2527/jas1982. 554826x

40. Morgan JB, Wheeler TL, Koohmaraie M, Savell JW, Crouse JD. Meat tenderness and the calpain proteolytic system in longissimus muscle of young bulls and steers. J Anim Sci. 1993;71:1471-6. https://doi.org/10.2527/1993.7161471x

41. Purchas RW, Burnham DL, Morris ST. Effects of growth potential and growth path on tenderness of beef longissimus muscle from bulls and steers. Anim Sci J. 2002;80:3211-21. https://doi.org/10.2527/2002.80123211x

42. Ouali A. Meat tenderization: possible causes and mechanisms. A review. J Muscle Food. 1990;1:129-65. https://doi.org/10.1111/j.1745-4573.1990.tb00360.x

43. Iwata $\mathrm{H}$, Obara $\mathrm{T}$, Kim BK, Baba A. Regulation of taurine transport in rat skeletal muscle. J Neurochem. 1986;47:158-63. https://doi.org/10.1111/j.1471-4159.1986.tb02844.x

44. Nishimura T, Ra Rhue M, Okitani A, Kato H. Components contributing to the improvement of meat taste during storage. Agric Biol Chem. 1988;52:2323-30. https://doi.org/10.1080/ 00021369.1988.10869028

45. Feidt C, Petit A, Bruas-Reignier F, Brun-Bellut J. Release of free amino-acids during ageing in bovine meat. Meat Sci. 1996;44:19-25. https://doi.org/10.1016/S0309-1740(96)00088-5

46. Wood JD, Richardson RI, Nute GR, Fisher AV, Campo MM, Kasapidou E, et al. Effects of fatty acids on meat quality: a review. Meat Sci. 2004;66:21-32. https://doi.org/10.1016/ S0309-1740(03)00022-6

47. Bas P, Chilliard Y, Morand-Fehr P, Rouzeau A, Mandran N. Composition of adipose tissue in Alpine goats during late lactation. Ann Zootech 1987;26:361-74.

48. Ali M, Baek KH, Lee SY, Kim HC, Park JY, Jo C, et al. Comparative meat qualities of Boston butt muscles (M. subscapularis) from different pig breeds available in Korean market. Food Sci Anim Resour. 2021;41:71. https://doi.org/10.5851/kosfa.2020.e79 